\title{
Effect of Postharvest Treatments on Quality and Shelf Life of Mandarin (Citrus reticulata Blanco)
}

\author{
Pradeep Raj Rokaya1, Dilli Ram Baral1, Durga Mani Gautam1, Arjun Kumar Shrestha1, \\ Krishna Prasad Paudyal ${ }^{2}$ \\ ${ }^{1}$ Agriculture and Forestry University, Rampur, Chitwan, Nepal \\ ${ }^{2}$ National Agricultural Research Institute (NARI), NARC, Khumaltar, Lalitpur, Nepal \\ Email: rokayapradeep@yahoo.com
}

Received 23 February 2016; accepted 17 May 2016; published 20 May 2016

Copyright (C) 2016 by authors and Scientific Research Publishing Inc.

This work is licensed under the Creative Commons Attribution International License (CC BY). http://creativecommons.org/licenses/by/4.0/

c) (7) Open Access

\begin{abstract}
Nepal produces large quantity of mandarin (Citrus reticulata Blanco) annually but faces big losses due to improper postharvest treatments. The experiment was carried out during 2012-2013 with the objective of assessing the effect of different postharvest treatments on quality and shelf life of mandarin. The postharvest treatments were: wax emulsion at $10 \%$, bavistin at $0.1 \%$, wax at $10 \%$ with bavistin at $0.1 \%$, calcium chloride at $1 \%$, Jeevatu at $5 \%$ along with untreated fruits as a control. The experiment was conducted for four weeks of storage at ambient condition in Nepal Agricultural Research Council, Khumaltar, Kathmandu. Wax in combination with bavistin was found as the most effective in reducing the physiological loss in weight, whereas bavistin proved to reduce decay loss up to four weeks of storage. The fruits treated with wax alone and with combination of bavistin retained maximum firmness, juice percentage, vitamin $C$ and palatability rating during the storage. The minimum total soluble solid and maximum titrable acidity were recorded in the fruits treated with wax plus bavistin. The present findings indicate that mandarin can be stored up to four weeks when treated with wax as well as wax with bavistin in the condition with $14^{\circ} \mathrm{C}-18^{\circ} \mathrm{C}$ temperature and $45 \%-73 \%$ relative humidity.
\end{abstract}

\section{Keywords}

Mandarin, Fruit Quality, Postharvest Treatments, Palatability Rating and Postharvest Loss in Weight

\section{Introduction}

Mandarin (Citrus reticulata Blanco) is a most promising fruit crop that stands in first position of the total fruit

How to cite this paper: Rokaya, P.R., Baral, D.R., Gautam, D.M., Shrestha, A.K. and Paudyal, K.P. (2016) Effect of Postharvest Treatments on Quality and Shelf Life of Mandarin (Citrus reticulata Blanco). American Journal of Plant Sciences, 7, 1098-1105. http://dx.doi.org/10.4236/ajps.2016.77105 
industry in Nepal. The country produces a large quantity of mandarin in its hilly areas from east to west comprising fifty four districts. It shares 0.97 percent in AGDP and 0.33 percent in GDP [1]. The country exports mandarin to India, China, Bangladesh, Bhutan, Pakistan and other countries about 600 tonnes annually [2].

Since mandarin is a non-climacteric and perishable fruits, it cannot be kept for a long time during transportation and storage. Mandarin fruits can be kept hardly for $1-2$ weeks depending upon temperature and humidity. The large volume of the losses starts right from harvesting and loss increases many folds during the postharvest steps. Worldwide postharvest loss in fruits and vegetables are as high as $30 \%-40 \%$ and even much higher in developing countries like Nepal [3]. Improper postharvest handling practices lead to inferior fruit quality and fetch poor market price. In mandarin, loss of $20 \%-25 \%$ has been reported during transportation from field to market [4]. The methods of harvesting, injury to fruit during harvesting, and weather conditions during harvest greatly determine the extent of decay losses during subsequent handling and storage [5]. Losses of mandarin fruits during the harvesting, handling and marketing are 25\% - 30\% [6]. Generally, mandarin fruits after harvest show the great losses and become non-accepted by consumer in the market. Loss is greatly influenced by the improper methods of harvesting, handling, packaging and transportation. Qualitative losses (such as loss of caloric and nutritive value, loss of acceptability by consumers, and loss of edibility) are more difficult to measure than quantitative losses of fresh fruits [7]. The prevalence of high inoculums of pathogens in the orchards due to poor plant protection measures besides non-adoption of scientific harvesting, handling, transit, storage, and antimicrobial treatments leads to heavy losses of fruits after harvest [8]. Various viable technologies like use of fungicides, cold storage, controlled atmosphere storage, anti-transpirants, wax coating, growth retardants, irradiation, and different types of packaging materials, etc. have been used to increase the shelf life of harvested fruits in past decades [9]. Postharvest treatments play a significant role in extending shelf life of the fruits [10]. Nepal faces big losses of mandarin annually due to not adopting proper postharvest handling practices during harvesting, transportation and storage. Hence, to minimise these postharvest losses and to maximise the quantitative and qualitative parameters along with prolongation of storage capacity, postharvest treatments with wax and other safe fungicides are urgent for effective marketing of mandarin in the country.

\section{Materials and Methods}

The present study was carried out at Nepal Agriculture Research Council (NARC), Kathmandu to assess the different postharvest treatments during 2012-2013 with the objective of managing the postharvest losses during storage condition. Fully ripe, greenish yellow, well matured and healthy mandarin fruits were clipped and brought from Lamjung district and fruits were washed with tap water then air-dried under the shade. These cleaned fruits were graded according to uniformity in size and immersed in emulsion for two minute then dried under shade. Eighty fruits from each treatment were kept on tray and stored in ambient condition $\left(16^{\circ} \mathrm{C}+2^{\circ} \mathrm{C}\right.$ and $45 \%-73 \% \mathrm{RH})$. The experiment was laid out in completely randomised design comprising six treatments i.e. $\mathrm{T}_{1}=$ untreated fruits (control), $\mathrm{T}_{2}=$ wax $10 \%, \mathrm{~T}_{3}=$ bavistin $0.1 \%, \mathrm{~T}_{4}=$ wax $10 \%$ with bavistin $0.1 \%, \mathrm{~T}_{5}=$ calcium chloride $1 \%$ and $\mathrm{T}_{6}=$ jeevatu $5 \%$ (package of beneficial microbes) with four replications. The observations on various parameters were recorded at weekly intervals up to four weeks of storage. Respiratory losses in terms of fruit weight and decay loss were determined and calculated on the basis of percent weight loss and percent decayed fruits. Fruit firmness was taken with penetrometer (effigy oil model having $8 \mathrm{~mm}$ tip). As a quality parameter, TSS was determined with help of refractometer corrected at $20^{\circ} \mathrm{C}$, acidity, and vitamin $\mathrm{C}$ was determined as per outlined by AOAC [11]. The palatability rating of the fruits was conducted by a panel of five judges on the basis of fruit colour, texture, aroma and taste using hedonic rating $1-5$. Fruits scoring a minimum of 3 out of 5 were regarded as acceptable form from the consumer point of view. Finally, the data were tabulated in excel sheet and analysed with statistical method mentioned by Gomez and Gomez [12].

\section{Results and Discussion}

\subsection{Physiological Loss in Weight (PLW)}

Physiological loss in weight (PLW) was significantly increased in all the treatments with the advancement of the storage period and the increasing trends in the weight loss percentage was found maximum in the fruits with untreated as a control in each week up to the 4th week of storage period. Minimum percentage of PLW was observed in the fruits treated with wax in combination with bavistin in all the weeks during storage and the losses 
ranged from $3.02 \%$ in the 1 st week to $9.81 \%$ in the 4 th week which was statistically at par with the findings of wax $10 \%$ (3.09 to $10.18 \%)$ whereas maximum weight loss was recorded in the fruits with control $(6.41 \%$ to 21.41\%) during the storage (Table 1).

This minimum weight loss in the wax treated fruits might be due to retardation in the process of transpiration and respiration by closing of lenticels and stomata of the cell wall of the fruits. The losses in fruit weight and moisture content of the peel were mainly caused by fruit transpiration in which water moved out and resulted in wilted rind and a shrivelled appearance [13]. Thus, wax emulsion might have been an effective treatment to reduce weight loss by checking the stomata and lenticels of the cell wall of the fruits which reduces the rate of transpiration and respiration. [14] claimed that wax coated fruit retained better glossiness and fresh appearance being a moisture barrier. These findings were in consonance with the report of the Bhusal [15], Bastakoti and Gautam [16] in mandarin, Chaudhary and Dhaka [17] in kinnow mandarin, Deka et al. [10] in Khasi mandarin, Ahmad et al. [18] in kinnow mandarin, Yadav et al. [9], in kinnow mandarin, and Bhullar [19] in sweet orange who found minimum weight loss in the fruits treated with wax emulsion.

\subsection{Decay Loss}

The perusal from data shown in Table 1 the decay loss increased significantly with the prolongation of storage period irrespective of the treatments. The decay loss was noticed from the first week of the storage in untreated fruits (control) and it was appeared from the second week in other treatments except bavistin. Decay loss was found significantly in the third week of the storage in all treatments. The minimum decay loss was noticed in the fruits with bavistin alone (0.7\%) followed by combination of wax $10 \%$ + bavistin $0.1 \%(1.3 \%)$, and wax at $10 \%$ (3.6\%) whereas the maximum decay loss was observed in the fruits with untreated (control) at the end of storage. The minimum decay loss in the bavistin and wax treated fruits might be due to inhibition of the moisture and microbial agent particularly. Yadav et al. [9] reported that the minimum decay loss might be due to interaction effect of wax coating as a microbial inhibitor as well as moisture inhibitor. Similar results on the decay loss were observed by Chaudhary and Dhaka [17] in kinnow mandarin, Mahajan et al. [14] in Asian Pear, Gautam et al. [20] in mango, Ahmad et al. [18] in kinnow mandarin, Bhusal [15] in mandarin, Hasan et al. [21], Deka et al. [10] in Khasi mandarin, and Yadav et al. [9] in kinnow mandarin, who reported minimum decay loss using the wax and wax like safe fungicide during the storage.

\subsection{Fruit Firmness}

The fruit firmness was decreased with the advancement of the storage period in all the treatments. Table 2 shows that the decreasing trend was started from the first week to the end of storage in all the treatments. At the first week, the wax at $10 \%$ in combination with bavistin at $0.1 \%$ treated fruits resulted in the more intact (4.16 $\left.\mathrm{kg} / \mathrm{cm}^{2}\right)$ and the lowest was recorded in the fruits with control $\left(3.78 \mathrm{~kg} / \mathrm{cm}^{2}\right)$. At the end of the storage, the firmness was observed maximum in the fruits treated with wax $10 \%$ plus bavistin $0.1 \%\left(3.08 \mathrm{~kg} / \mathrm{cm}^{2}\right)$ followed by wax $10 \%\left(3.03 \mathrm{~kg} / \mathrm{cm}^{2}\right)$ and the lowest firmness was found in the fruits with control $\left(2.09 \mathrm{~kg} / \mathrm{cm}^{2}\right)$. The decline

Table 1. Effect of postharvest treatments on PLW and decay loss percentage.

\begin{tabular}{|c|c|c|c|c|c|c|c|c|}
\hline \multirow{3}{*}{ Treatments } & \multicolumn{4}{|c|}{ Physiological loss in weight (\%) } & \multicolumn{4}{|c|}{ Decay loss (\%) } \\
\hline & \multicolumn{4}{|c|}{ Weeks of storage } & \multicolumn{4}{|c|}{ Weeks of storage } \\
\hline & 1 & 2 & 3 & 4 & 1 & 2 & 3 & 4 \\
\hline Control & 6.41 & 12.86 & 17.44 & 21.41 & 1.89 & 4.46 & 7.39 & 16.70 \\
\hline Wax $10 \%$ & 3.09 & 6.35 & 8.06 & 10.18 & 0.00 & 0.92 & 1.76 & 3.60 \\
\hline Bavistin $0.1 \%$ & 5.50 & 10.9 & 14.29 & 17.18 & 0.00 & 0.00 & 0.27 & 0.70 \\
\hline Wax $10 \%$ + Bavistin $0.1 \%$ & 3.02 & 5.98 & 7.84 & 9.81 & 0.00 & 0.00 & 0.56 & 1.30 \\
\hline $\mathrm{CaCl}_{2} 1 \%$ & 5.61 & 10.65 & 14.93 & 18.07 & 0.00 & 2.39 & 3.25 & 5.30 \\
\hline Jeevatu 5\% & 5.78 & 11.19 & 14.84 & 17.87 & 0.00 & 2.37 & 3.77 & 6.10 \\
\hline $\mathrm{CD}$ at $5 \%$ & 0.85 & 1.14 & 1.19 & 1.47 & NS & NS & 4.14 & 7.40 \\
\hline
\end{tabular}

NS: Non-significant. 
Table 2. Effect of postharvest treatments on fruit firmness and juice recovery percentage.

\begin{tabular}{|c|c|c|c|c|c|c|c|c|}
\hline \multirow{3}{*}{ Treatments } & \multicolumn{4}{|c|}{ Fruit firmness $\left(\mathrm{kg} / \mathrm{cm}^{2}\right)$} & \multicolumn{4}{|c|}{ Juice recovery (\%) } \\
\hline & \multicolumn{4}{|c|}{ Weeks of storage } & \multicolumn{4}{|c|}{ Weeks of storage } \\
\hline & 1 & 2 & 3 & 4 & 1 & 2 & 3 & 4 \\
\hline Control & 3.78 & 3.16 & 2.59 & 2.09 & 47.26 & 42.89 & 38.80 & 34.65 \\
\hline Wax $10 \%$ & 4.07 & 3.17 & 3.37 & 3.03 & 49.49 & 47.64 & 45.87 & 43.45 \\
\hline Bavistin $0.1 \%$ & 3.94 & 3.56 & 3.16 & 2.83 & 47.81 & 45.86 & 43.60 & 40.92 \\
\hline Wax 10\% + Bavistin 0.1\% & 4.16 & 3.79 & 3.42 & 3.08 & 49.56 & 47.84 & 45.95 & 43.81 \\
\hline $\mathrm{CaCl}_{2} 1 \%$ & 3.91 & 3.53 & 3.12 & 2.68 & 47.57 & 45.30 & 42.44 & 39.78 \\
\hline Jeevatu 5\% & 3.88 & 3.49 & 3.03 & 2.61 & 48.09 & 45.71 & 42.83 & 40.66 \\
\hline $\mathrm{CD}$ at $5 \%$ & NS & 0.35 & 0.45 & 0.40 & NS & NS & 4.19 & 4.62 \\
\hline
\end{tabular}

NS: Non-significant.

in the firmness might be due to moisture loss from the fruits cells. The wax alone or in combination with bavistin showed the more intact (firmness) than other treatments. It might be due to wax alone or in combination with other fungicides acts as moisture and microbial inhibitor that reduces the respiration and transpiration of the fruits. Mahajan et al. [14] reported that wax coat fruits reduced the moisture loss from the surface, thus maintain cell wall integrity and tissue rigidity. Sidhu et al. [22] and Yadav et al. [9] reported that the firmness decreased with the increase in storage period.

\subsection{Juice Recovery}

Table 2 shows that the juice recovery percentage was decreased with time during the storage in all the treatments. Wax treated fruits recorded the maximum juice recovery percentage in all the weeks. In the first week, the higher juice percentage was obtained in the wax $10 \%$ plus bavistin $0.1 \%(49.56 \%)$ which was statistically at par with wax 10\% (49.49\%) as against control (47.26\%). The trend in decrease in juice percentage during the storage was might be due to loss of moisture from the surface of the fruits. The minimum decrease in juice percentage was observed in the fruits treated with wax $10 \%$ plus bavistin $0.1 \%$ from the 1 st week $(49.56 \%)$ to the 4th week (43.81\%) followed by wax $10 \%$ from the 1 st week $(49.49 \%)$ to the 4 th week $(43.45 \%)$ as against control from the 1 st week (47.26\%) to the $4^{\text {th }}$ week (34.65\%). There was significant decrease in the juice percentage of untreated fruits (control) than treated fruits. The fruits treated with wax and in combination with bavistin showed low reduction in juice content during storage as compared to other chemically treated fruits and control. This might be due the fact that the wax acted as a barrier which had checked the losses of the moisture from the fruit surface. Similar results were also reported by Yadav et al. [9] in kinnow mandarin, Sonkar et al. [8] in kinnow mandarin, Sharma and Ghuman [23] in kinnow fruits, and Deka et al. [10] in khasi mandarin.

\subsection{Total Soluble Solid (TSS)}

TSS is one of the major indicators to judge the quality of the mandarin fruits. As shown in Table 3, TSS increased with the increasing period of storage in all the treatments and the increasing trend was higher in untreated fruits (control) than the treated fruits with different chemicals. Untreated (control) fruits showed the maximum TSS content during the storage and ranged from the 1 st week $\left(10.92^{\circ}\right.$ Brix $)$ to the 4 th week $\left(12.88^{\circ}\right.$ Brix) and minimum TSS was recorded in the fruits treated with wax $10 \%$ from the 1 st week $\left(10.35^{\circ}\right.$ Brix $)$ to the 4th week (11.51 ${ }^{\circ}$ Brix) which was at par with wax $10 \%$ in combination with bavistin $0.1 \%$ from the 1 st week $\left(10.39^{\circ}\right.$ Brix) to the 4 th week $\left(11.65^{\circ}\right.$ Brix). The trend showed that wax treated fruits was significantly superior because of the gradual increment in the TSS change whereas in control, it was increased at faster pace.

The faster TSS increment in the untreated fruits might be due to faster metabolic activities through respiration and transpiration than in treated fruits with different chemicals. Jholgiker and Reddy [24] claimed that the gradual increment in TSS of fruits treated with coating material may be justified by the twin role of coating material, acting as a physical barrier for transpiration losses and creating a modified atmosphere resulting in building of internal $\mathrm{CO}_{2}$ and depletion of $\mathrm{O}_{2}$. Similar results were noticed by Sidhu et al. [22] in pear; Deka et al. [10], 
Table 3. Effect of postharvest treatments on TSS and TA.

\begin{tabular}{|c|c|c|c|c|c|c|c|c|}
\hline \multirow{3}{*}{ Treatments } & \multicolumn{4}{|c|}{ TSS ( Brix) } & \multicolumn{4}{|c|}{ Titrable acidity (\%) } \\
\hline & \multicolumn{4}{|c|}{ Weeks of storage } & \multicolumn{4}{|c|}{ Weeks of storage } \\
\hline & 1 & 2 & 3 & 4 & 1 & 2 & 3 & 4 \\
\hline Control & 10.92 & 11.45 & 12.10 & 12.88 & 0.86 & 0.75 & 0.65 & 0.53 \\
\hline Wax $10 \%$ & 10.35 & 10.67 & 11.09 & 11.51 & 0.91 & 0.83 & 0.75 & 0.69 \\
\hline Bavistin 0.1\% & 10.44 & 11.06 & 11.30 & 11.87 & 0.90 & 0.82 & 0.75 & 0.67 \\
\hline Wax 10\% + Bavistin 0.1\% & 10.39 & 10.79 & 11.44 & 11.65 & 0.93 & 0.86 & 0.78 & 0.73 \\
\hline $\mathrm{CaCl}_{2} 1 \%$ & 10.35 & 10.99 & 11.36 & 11.82 & 0.89 & 0.83 & 0.74 & 0.67 \\
\hline Jeevatu 5\% & 10.62 & 11.06 & 11.60 & 11.99 & 0.88 & 0.79 & 0.72 & 0.65 \\
\hline CD at $5 \%$ & NS & NS & NS & 0.60 & NS & 0.70 & 0.07 & 0.06 \\
\hline
\end{tabular}

NS: Non-significant.

Ladaniya et al. [25] in Nagpur mandarin; and Mahajan et al. [14] in pear.

\subsection{Titrable Acidity (TA)}

The data presented in Table 3 revealed that the results pertaining to the effect of different levels of treatments to the titrable acidity (TA) was significant at the end of the storage of mandarin. The TA significantly decreased with the advancement of the storage period. The decreasing trend of acidity during the storage period was probably due to utilization of acid in tricarboxylic acid cycle in respiration process. The TA was recorded maximum in the fruits treated with wax $10 \%$ plus bavistin $0.1 \%(0.73 \%)$ at par with wax $10 \%(0.69 \%)$ as against control $(0.53 \%)$ at the end of the storage. The higher acidity in the wax treated fruits might be due to lesser utilization of the acids in the respiration process during the storage whereas untreated fruits had minimum acids was might be due to faster utilization of the acids in the respiration process during storage. The results are in line with the findings reported by Sonkar et al. [8] in kinnow mandarin, Jholgiker and Reddy [24] in Annona, Sidhu et al. [22] in pear, and Deka et al. [10] in khasi mandarin.

\subsection{Vitamin C}

A perusal from the data presented in Table 4 pertaining the effect of treatments to the vitamin $\mathrm{C}$ was found significant and decreasing with the advancement of the storage period in all the treatments. The maximum vitamin C was recorded in the fruits treated with wax $10 \%$ in combination with $0.1 \%$ bavistin $(33.26 \mathrm{mg} / 100 \mathrm{ml})$ which is statistically at par with wax $10 \%(32.85 \mathrm{mg} / 100 \mathrm{ml})$ as against control $(29.28 \mathrm{mg} / 100 \mathrm{ml})$ in the first week. Likewise, vitamin C wax maximum in the fruits treated with wax $10 \%$ plus bavistin $0.1 \%(24.65 \mathrm{mg} / 100 \mathrm{ml})$ which was statistically at par with wax $10 \%(24.16 \mathrm{mg} / 100 \mathrm{ml})$ as against of control $(18.86 \mathrm{mg} / 100 \mathrm{ml})$. The decreasing trend in the vitamin $\mathrm{C}$ was probably due to degradation of the ascorbic acid during the storage. Lee and Kader [26] suggested that loss of vitamin $C$ is caused by leaching in surrounding water and thermal breakdown. The retention of the vitamin $\mathrm{C}$ in the wax treated fruits might be due to less degradation of the ascorbic acid in the storage. These findings were supported with findings of Sonkar et al. [8] in kinnow mandarin, Deka et al. [10] in Khasi mandarin, Ladaniya et al. [25] in Nagpur mandarin, Ahmad et al. [18] in kinnow mandarin who reported that wax treated fruits retained the maximum vitamin $\mathrm{C}$ content.

\subsection{Palatability Rating}

The fruits treated with different chemicals were evaluated in respect of palatability and the rating was found decreasing trend during the storage. Table 4 shows that Mandarin flavour quality is often rapidly lost after fruits are picked or commercially packed. The highest rating (4.56) was recorded in the fruits treated with wax $10 \%$ alone and in combination with bavistin which was statistically at par with the other chemically treated fruits as against of control (4.22) in the 1st week. However, rating was found maximum in the fruits treated with wax $10 \%$ plus bavistin $0.1 \%$ (3.48) which was statistically at par with wax $10 \%$ (3.46) as against of control (2.43). The 
Table 4. Effect of postharvest treatments on vitamin C and sensory evaluation.

\begin{tabular}{|c|c|c|c|c|c|c|c|c|}
\hline \multirow{3}{*}{ Treatments } & \multicolumn{4}{|c|}{ Vitamin C (mg/100ml) } & \multicolumn{4}{|c|}{ Sensory evaluation (1 - 5 scale) } \\
\hline & \multicolumn{4}{|c|}{ Weeks of storage } & \multicolumn{4}{|c|}{ Weeks of storage } \\
\hline & 1 & 2 & 3 & 4 & 1 & 2 & 3 & 4 \\
\hline Control & 29.28 & 25.37 & 22.22 & 18.86 & 4.22 & 3.68 & 3.06 & 2.43 \\
\hline Wax $10 \%$ & 32.85 & 29.12 & 25.89 & 24.16 & 4.56 & 4.25 & 3.93 & 3.46 \\
\hline Bavistin $0.1 \%$ & 31.42 & 27.99 & 24.63 & 22.54 & 4.40 & 4.09 & 3.64 & 3.22 \\
\hline Wax 10\% + Bavistin 0.1\% & 33.26 & 29.62 & 26.46 & 24.65 & 4.56 & 4.26 & 3.93 & 3.48 \\
\hline $\mathrm{CaCl}_{2} 1 \%$ & 32.61 & 28.23 & 24.84 & 22.67 & 4.32 & 4.02 & 3.57 & 3.15 \\
\hline Jeevatu 5\% & 30.34 & 26.45 & 23.40 & 21.10 & 4.28 & 4.01 & 3.53 & 3.12 \\
\hline CD at $5 \%$ & NS & NS & NS & 2.91 & 0.15 & 0.17 & 0.24 & 0.30 \\
\hline
\end{tabular}

NS: Non-significant.

treated fruits had showed the good appearance, sweet taste and desirable flavour and acceptable position during the storage. Among the treatments, only wax $10 \%$ plus bavistin $0.1 \%$ (3.48) followed by wax $10 \%$ (3.46) had showed the acceptable position. The lowest rating was recorded in the fruits with control (2.43) which is below of the acceptable position. The decrease in the palatability with time was might be due to ascribed to certain bio-chemical changes in the fruits.

Chemically treated fruits had acceptable colour, glossy appearance, sweet taste, and good flavour that might be due to the fact that chemical treatments acts a barrier to the moisture loss and rapid respiration and transpiration loss. Control fruits had higher rate of metabolic activities with respiration and transpiration, thus dislike by the people. Orange-like flavour decreased not as a consequence of an increment in the ethanol content, but because of other, minimal chemical changes that took place during storage [27]. From the above facts it can be concluded that waxed fruits had fresh, glossy external which is highly acceptable in the market up to the $4^{\text {th }}$ week of storage and fruits without treatments observed as dull and shrivelled appearance and those could not acceptable up to the $2^{\text {nd }}$ week. The findings were in corroboration with the findings of Sindhu et al. [22] in pear, Choudhary and Dhaka [17] in kinnow mandarin, Mahajan et al. [14] in pear, Karibasappa and Gupta [28] in khasi mandarin, Singhrot et al. [29] in lemon who reported that palatability was decreased with time during the storage.

\section{Conclusion}

From findings drawn as above, we can conclude that postharvest losses can be minimised by treating mandarin fruit with different fungicides to prolong the shelf life and to enhance fruit quality. Wax alone and in combination with bavistin reduced the weight and decay loss as well as improved the internal quality of the fruits. Fruits treated with wax and with bavistin can be stored up to four weeks at the condition of $14^{\circ} \mathrm{C}-18^{\circ} \mathrm{C}$ temperature and $45 \%-73 \% \mathrm{RH}$. This study will be a milestone to use different postharvest treatments to reduce postharvest losses in the storage.

\section{Acknowledgements}

The authors are thankful to Director General of Department of Food Technology and Quality Control (DFTQC) of Ministry of Agricultural Development, and to the chief of postharvest research unit of NARC, Khumaltar, Lalitpur for providing laboratory facility during the experiment.

\section{References}

[1] PMD (2012) Postharvest Management and Value Addition of Fruits in Production Catchments in Nepal. A Project Submitted to SAARC Development Fund (SDF) Secretariat, Postharvest Management Directorate, Shreemahal, Kathmandu, Nepal, 1-16.

[2] TEPC (2013) Statistical Information. Trade and Export Promotion Center, Lalitpur, Kathmandu, Nepal.

[3] Bhattarai, R.M., Rijal, R.K. and Mishra, P. (2013) Postharvest Losses in Mandarin Orange: A Case Study of Dhankuta 
District of Nepal. African Journal of Agricultural Research, 8, 763-767.

[4] PHLRD (2005) Food Loss Status in Nepal. Progress Report. Postharvest Loss Reduction Division, Postharvest Management Directorate, Kathmandu, Nepal, 3.

[5] Ladaniya, M.S. (2008) Citrus Fruit: Biology, Technology and Evaluation. Elsevier Inc., Atlanta, USA, 1-10. http://dx.doi.org/10.1016/B978-012374130-1.50003-6

[6] Singh, S. (2001) Citrus Industry of India. In: Singh, S. and Naqvi, S.A.M.H., Eds., Citrus, International Book Distributing Company, Lucknow, India, 1-44.

[7] Kader, A.A. (2005) Increasing Food Availability and Reducing Postharvest Losses of Fresh Produce. Proceedings of the 5th International Postharvest Symposium, Verona, 6-11 June 2004, 2169-2175. http://dx.doi.org/10.17660/ActaHortic.2005.682.296

[8] Sonkar, R.K., Sarnaik, D.A., Dikshit, S.N. and Saxena, R.R. (2009) Individual Stretch Cling Film Wrapped Kinnow Mandarin under Ambient Storage. Indian Journal of Horticulture, 66, 22-27.

[9] Yadav, M., Kumar, N., Singh, D.B. and Singh, G.K. (2010) Effect of Postharvest Treatments on Shelf Life and Quality of Kinnow Mandarin. Indian Journal of Horticulture, 67, 243-248.

[10] Deka, B.C., Sharma, S. and Borah, S.C. (2006) Postharvest Management Practices for Shelf Life Extension of Khasi Mandarin. Indian Journal of Horticulture, 63, 251-255.

[11] A.O.A.C. (2005) Official Methods of Analysis. Association of Official Analytical Chemists, Washington DC, USA.

[12] Gomez, A.K. and Gomez, A.A. (1984) Statistical Procedures for Agricultural Research. John Wiley and Sons Inc., New York.

[13] Wills, R., McGlasson, B., Graham, D. and Joyce, D. (2007) Postharvest: An Introduction to the Physiology and Handling of Fruit, Vegetables and Ornamentals. 2nd Edition, University of New South Wales Press, Sydney.

[14] Mahajan, B.V.C., Datta, A.S. and Dhillon, W.S. (2004) Effect of Pre-Storage Treatments on the Quality and Storage Life of Asian Pear. Indian Journal of Horticulture, 61, 342-344.

[15] Bhusal, Y. (2002) Improvement of Postharvest Shelf Life of Mandarin Orange (Citrus reticulate Blanco), M.Sc. Thesis, Institute of Agriculture and Animal Science (IAAS), Rampur, Chitwan, Nepal.

[16] Bastakoti, P. and Gautam, D.M. (2007) Effect of Maturity Stages and Postharvest Stages on Shelf Life and Quality of Mandarin Orange in Modified Cellar Store. Journal of Institute of Agriculture and Animal Science, 28, 65-74.

[17] Choudhary, M.R. and Dhaka, R.S. (2005) Effect of Different Postharvest Treatments on Quality of Kinnow Mandarin Fruits during Storage. Haryana Journal of horticulture Science, 34, 39-41.

[18] Ahmad, M.S., Thakur, K.S. and Kaushal, B.B.L. (2005) Post-Harvest Treatments to Reduce Postharvest Losses in Kinnow Mandarin. Indian Journal of Horticulture, 62, 63-67.

[19] Bhullar, J.S. (1981) Effect of Wax Emulsion, Benlate and Some Growth Regulators on the Storage Life of Pineapple Sweet Orange. Haryana Journal Horticulture Science, 10, 147-150.

[20] Gautam, B., Sarkar, S.K. and Reddy Y.N. (2003) Effect of Post-Harvest Treatments on Shelf Life and Quality of Banganapalli Mango. India Journal of Horticulture, 60, 135-139.

[21] Hassan, Z.H., Lesmayati, S., Qomariah, R. and Hasbianto, A. (2014) Effects of Wax Coating Applications and Storage Temperatures on the Quality of Tangerine Citrus (Citrus reticulata) var. Siam Banjar. International Food Research Journal, 21, 641-648.

[22] Sidhu, G.S., Dhillon, W.S. and Mahajan, B.V.C. (2006) Effect of Waxing and Packaging on Storage and Shelf Life of Pear cv. Punjab Beauty. Haryana Journal of Horticulture Science, 35, 51-56.

[23] Sharma, A. and Ghuman, B.S. (2009) Evaluation of On-Farm Waxing and Grading Prototype for Fresh Kinnow Fruits. Indian Journal of Horticulture, 66, 288-290.

[24] Jholgiker, P. and Reddy, B.S. (2007) Effect of Different Surface Coating Material on Post-Harvest Physiology of Annona squamosa L. Fruits under Ambient and Zero Energy Cool Chamber Storage. Indian Journal of Horticulture, 64, 41-44.

[25] Ladaniya, M.S., Singh, S. and Mahalle, B. (2005) Sub-Optimum Low Temperature of "Nagpur” Mandarin as Influenced by Wax Coating and Intermitant Waxing. Indian Journal of Horticulture, 62, 1-7.

[26] Lee S.K. and Kader, A.A. (2000) Pre-Harvest and Postharvest Factors Influencing Vitamin C Content of Horticultural Crops. Postharvest Biology and Technology, 20, 207-220. http://www.elsevier.com/locate/postharvbio http://dx.doi.org/10.1016/S0925-5214(00)00133-2

[27] Marcilla, A., Zarzo, M. and del Río, M.A. (2006) Effect of Storage Temperature on the Flavour of Citrus Fruit. Spanish Journal of Agricultural Research, 4, 336-344. http://dx.doi.org/10.5424/sjar/2006044-210 
[28] Karibasappa, G.S. and Gupta, P.N. (1988) Storage Studies of Khasi Mandarins. Haryana Journal of Horticulture Science, 17, 196-200.

[29] Singhrot, R.S., Sharma, R.K., Sandooja, J.K. and Singh, J.P. (1987) Effect of Some Chemicals to Enhance Shelf Life of Baramasi lemon. Haryana Journal of Horticulture Science, 16, 25-30. 